\title{
The Value of Flexible Bronchoscopy in the Neonatal Intensive Care Unit
}

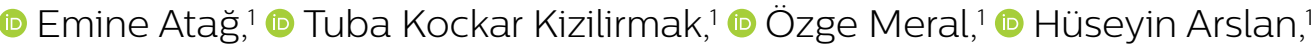 \\ (D) Esra Yayla Korkmaz, ${ }^{2}$ (1) Edanur Merttürk, ${ }^{2}$ (1) Fusun Unal, ${ }^{2}$ \\ (1) Semra Gündoğdu, ${ }^{2}$ (D) Binay Vatansever, ${ }^{2}$ (1) Sedat Öktem ${ }^{1}$
}

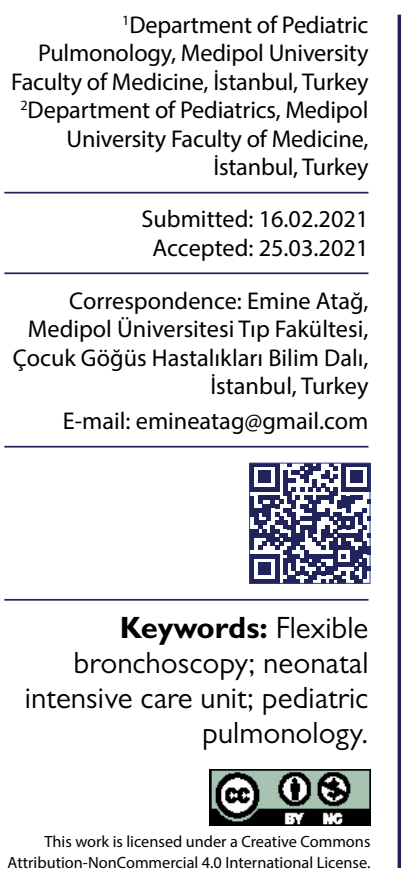

\section{ABSTRACT}

Objective: Flexible bronchoscopy (FB) is a safe and valuable tool for the assessment and treatment of patients in neonatal intensive care units (NICUs) with respiratory diseases.

Methods: All neonates who underwent FB in the NICU between July 2014 and July 2020 were included in the study. All demographic and clinical data including FB indications, the FB procedure performed and FB findings, FB complications, and the contribution of $F B$ to the management were examined.

Results: Forty-eight patients underwent FB. Twenty-two (45.8\%) of them were male. The median age was 44 days (26.2-59.7). The most common indication for FB was extubation failure at $50 \%$, followed by suspected airway disease at $33 \%$. Bronchoscopic assessments revealed at least one abnormality in 46 (95.8\%) infants. Bronchoalveolar lavage (BAL) was performed in $4 \mathrm{I}(85.4 \%)$ patients. FB contributed to the management in 46 (93.8\%) of the patients. Based on FB results, 16 of 48 (33.3\%) patients received a diagnosis by bronchoscoPy, and medical treatments were revised in $23(48 \%)$ patients. A successful therapeutic lavage was made in 7 (14.6\%) of patients. Surgical interventions were performed in $28(58.3 \%)$ of the patients.

Conclusion: FB has an important value in the diagnosis and management of respiratory disorders in NICU. Direct visualization of the airways, microbiological assessment of BAL, and removal of mucus plugs allow the clinicians to make an accurate diagnosis and provide appropriate treatment options, including airway surgical procedures.

\section{INTRODUCTION}

Despite the advances in neonatal medical care, respiratory disorders still constitute the predominant cause of morbidity and mortality in neonatal intensive care unit (NICU). A low-risk diagnostic method that will guide the diagnosis and treatment related to the respiratory system is of great importance to improve the outcomes. ${ }^{[1,2]}$ Flexible bronchoscopy (FB) is a safe and valuable tool for the assessment and treatment of infants and children with a variety of pediatric respiratory diseases including congenital-acquired airway abnormalities, persistent infiltrations, and atelectasis. Increased clinical experience over the last decades and recent developments in the field of endoscopic technology ensure that FB can be used safely in very young age groups such as newborns. [3-5] In this study, we aimed to investigate the diagnostic and therapeutic contribution and safety of FB in the NICU.

\section{MATERIALS AND METHODS}

All neonates admitted to the NICU at our hospital between July 2014 and July 2020 were reviewed retrospectively. Medical records of the neonates who underwent FB were evaluated. All demographic and clinical data including $F B$ indications, the FB procedure performed and FB findings, FB complications, and the contribution of FB to the management were examined.

FB indications were as follows: Extubation failure, defined as the replacement of an intubation tube within $<48 \mathrm{~h}$ after extubation; suspected airway disease includes infants with stridor, unexplained tachypnea, retractions, and a history of prior intubation; persistent infiltration, defined as persistent findings on chest X-ray despite 2-week broad-spectrum antibiotic treatment; and persistent atelectasis defined as the persistence of atelectasis after I-week chest physiotherapy plus bronchodilators and mucolytics including inhaled hypertonic saline and dornase alpha. 
All FBs were performed by same experienced pediatric pulmonologist in the operating room using Karl Storz flexible bronchoscopes with a $3.6 \mathrm{~mm}$ outer diameter. The bronchoscope was introduced through a facemask and/ through catheter mount or laryngeal mask depending on the clinical condition of the patients. The upper airways were evaluated with the facemask before the laryngeal mask was placed. Supplemental oxygen was used routinely to avoid desaturations through a facemask or laryngeal mask. Anesthesia and sedation were delivered by an anesthetist intravenously or through inhalation and titrated to preserve the patients' spontaneous breathing. Oxygen saturation, heart rate, and blood pressure were monitored in all patients during and after $\mathrm{FB}$ with pulse oximetry and electrocardiography. Bronchoalveolar lavage (BAL) was performed with the use of normal saline with a volume of $3 \mathrm{~mL} / \mathrm{kg}$ administered in three divided doses. ${ }^{[2,6]}$ BAL was taken from a segmental bronchus based on radiographic findings or findings at the time of the bronchoscopy, as well as routinely from the lingula and right middle lobe. BAL was sent for bacterial and fungal cultures. Major complications due to FB that required termination of the procedure were recorded. The contribution of $\mathrm{FB}$ to the management was defined as follows: (I) providing a diagnosis that is not obtainable with other diagnostic modalities, (2) allowing the treatment by removal of bronchial plugs, (3) providing the initiation of new medical treatments including chest physiotherapy and appropriate antibacterial treatment according to the microbiological assessment of $\mathrm{BAL}$, and (4) providing the selection of patients who require surgical treatment.

Statistical analysis was performed using SPSS software (version 23.0; IBM SPSS Statistics, Chicago, IL). Continuous variables are expressed as mean \pm SD for normally distributed data or median $\left(25^{\text {th }}\right.$ and $75^{\text {th }}$ percentile) for data that were not normally distributed. Categorical data are expressed as $n$ (\%). The Wilcoxon test (two related-samples tests) was used to analyze the comparisons.

The study was approved by the Ethical Committee of our hospital (committee approval number 604.01.01-E.19393).

\section{RESULTS}

During the study period, 48 patients underwent FB. Twenty-two (45.8\%) of them were male. The median age was 44 days (26.2-59.7), the youngest patient was a 7-day old baby. Twenty-eight $(58.3 \%)$ were intubated, $13(27.1 \%)$ patients were on high flow nasal cannula. The most common indication for $\mathrm{FB}$ was extubation failure at $50 \%$, followed by suspected airway disease at $33 \%$. The general characteristics of the patients are shown in Table I.

The bronchoscope was introduced through a facemask in $28(58 \%)$ and a laryngeal mask in 20 (42\%) patients. Bronchoscopic assessments revealed at least one abnormality in $46(95.8 \%)$ infants. The most common findings, laryngomalacia, and increased airway secretions were found in 17 (35.4\%) and I I (22.9\%) of the patients, respectively (Table
Table I. General characteristics of the patients

\begin{tabular}{lc}
\hline Median age (day) & $44(29.25-59.75)$ \\
Male & $22(45.8 \%)$ \\
Female & $26(54.2 \%)$ \\
Respiratory support prior to FB & \\
$\quad$ Entubation & $28(58.3 \%)$ \\
Oxygen support through hood & $13(27.1 \%)$ \\
or nasal cannula & \\
HFNC & $3(6.3 \%)$ \\
BIPAP & $3(6.3 \%)$ \\
None & $1(2 \%)$ \\
FB Indications & $25(52 \%)$ \\
Extubation failure & $16(33 \%)$ \\
Suspected airway disease & $7(14.5 \%)$ \\
Persistent atelectasis & $3(6.25 \%)$ \\
Persistent infiltration & $70.50(37.25-107.25)$ \\
Median length of stay in NICU & $26(14.25-42.75)$ \\
Median length of stay in NICU & \\
before FB & $33(12-71)$ \\
Median length of stay in NICU & \\
after FB & \\
\hline
\end{tabular}

Continuous variables are expressed as median $\left(25^{\text {th }}, 75^{\text {th }}\right.$ percentile) as data were not normally distributed. Categorical data are expressed as $n$ (\%). HFNC: High flow nasal cannula; BIPAP: Bi-level positive airway pressure; FB: Flexible bronchoscopy; NICU: Neonatal intensive care unit.

Table 2. The findings of $F B$ and culture results of $B A L$

\begin{tabular}{lc}
\hline Bronchoscopic findings & $\mathbf{n}(\%)$ \\
\hline Laryngomalacia & $17(35.4)$ \\
Increased airway secretions & $14(29.2)$ \\
Tracheomalacia & $8(16.8)$ \\
External compression & $8(16.8)$ \\
Granulation tissue & $6(12.5)$ \\
Laryngotracheobronchomalacia & $5(10.4)$ \\
Subglottic stenosis & $5(10.4)$ \\
Bronchomalacia & $4(8.4)$ \\
Abnormal bronchial anatomy & $4(8.4)$ \\
Tracheal stenosis/narrowing & $3(6.2)$ \\
Vocal cord paralysis & $2(4.2)$ \\
Tracheoesophageal fistula & $2(4.2)$ \\
Normal & $2(4.2)$ \\
Others & $3(6.2)$ \\
Culture results of BAL (n=4I) & \\
$\quad$ No growth/sterile & $24(58.5)$ \\
Klebsiella pneumonia & $10(24.3)$ \\
Pseudomonas aeruginosa & $3(7.3)$ \\
Staphylococcus aureus & $2(4.9)$ \\
Haemophilus influenzae & $1(2.4)$ \\
Streptococcus pneumoniae & $1(2.4)$ \\
\hline
\end{tabular}

Categorical data are expressed as $n$ (\%). FB: Fiberoptic bronchoscopy; BAL: Bronchoalveolar lavage.

2). BAL was performed in $4 \mathrm{I}(85.4 \%)$ patients. Microbiologic assessment of $B A L$ revealed at least one organism 
growth at $>10,000$ colony-forming units in $24(50 \%)$ patients. Klebsiella pneumonia was the most common bacteria and was identified in $10(24.3 \%)$ patients (Table 2).

FB contributed to the management in 46 (93.8\%) of the patients. Based on FB and BAL results, 16 of 48 (33.3\%) patients received a diagnosis by bronchoscopy, and medical treatments were revised in 23 (48\%) patients, including change of antibiotics in $12(25 \%)$ patients, and adding chest physiotherapy in II (22.9\%) patients. A successful therapeutic lavage (re-expansion of collapsed areas on chest radiograph) was made in 7 (14.6\%) of patients. Surgical interventions were performed in 28 (58.3\%) of the patients, 17 of whom underwent a tracheotomy. The median length of stay in NICU was 70.50 (37.25-107.25) days. The median length of stay in NICU before and after FB was similar $(p=0.06)$. No deaths related to bronchoscopy occurred and none of the patients had major complications during FB.

\section{DISCUSSION}

FB is increasingly used in neonatal intensive care due to its diagnostic and therapeutic value and safety. The visualization of the upper and lower airways, removal of the mucus plugs, and assessment of BAL provides accurate diagnosis and facilitate appropriate management of the patients. This study highlights the yield of FB in NICU. We found that $\mathrm{FB}$ was provided overall contributive information for the diagnosis and the management in $94 \%$ of the patients.

Since prolonged mechanical ventilation is associated with high mortality and morbidity, extubation should be planned as early as possible to minimize the risks of mechanical ventilation. ${ }^{[7]}$ However, extubation failure continues to be a problem in newborns and requires evaluation of the airways. ${ }^{[6,8]}$ In our study, extubation failure that occurred in half of the patients was the most common indication. Extubation could be performed without tracheostomy in $30 \%$ of these patients with treatments given according to $\mathrm{FB}$ and $\mathrm{BAL}$ results.

Congenital and acquired airway diseases occur commonly in NICU, as the small airways of neonates are vulnerable to obstruction. ${ }^{[9]}$ The second common indication was suspected airway disease, which was encountered in onethird of our patients. Similar to our results, a study evaluating the role of FB in NICU revealed that frequency the of airway problems among indications was $28 \%{ }^{[10]}$

In our study, persistent atelectasis and infiltration were other indications with an overall rate of $21 \%$. Newborns and infants are prone to atelectasis due to the anatomical features of the airways, excessive airway secretions, and secondary surfactant deficiency. ${ }^{[1]}$ Besides, pneumonia is one of the important causes constituting 6-32.3\% of nosocomial infections in NICU patients. ${ }^{[12]}$ The reported frequency of atelectasis and pneumonia among FB indications vary, as the classifications of indications differ between studies. Persistent radiological abnormalities including nosocomial pneumonia, atelectasis, or both were reported $28-44 \%{ }^{[13]}$
In our study, FB revealed abnormal findings in $96 \%$ of the patients. While this result was consistent with other studies conducted among newborns ranging from $91.6 \%$ to $98 \%$, it was higher than pediatric intensive care unit (PICU) studies with positive findings of $69-80 \%{ }^{[14,15]}$ This high rate of abnormal findings among newborns may be due to the anatomical and physiological features of the airways and selected indications.

FB is considered as the gold standard for the diagnosis of airway malacia. Airway malacia is one of the causes of airway obstructions and may cause a wide variety of symptoms from a persistent cough, persistent lower respiratory infections to respiratory failure depend on length, site, and severity of the malacic segment. ${ }^{[6]}$ According to the results of the pediatric bronchoscopic series, the frequency of malacia was reported as 31-34\%. ${ }^{[17]}$ Airway malacia may be primary (congenital) or secondary to external compression to the airways, positive pressure ventilation, or respiratory tract infections, which results in a high rate of malacia in $\mathrm{NICU} .^{[17]}$ In our study, the most common identified bronchoscopy findings were respiratory tract malacia including laryngomalacia, tracheomalacia, and bronchomalacia. Fifty-eight percent of the patients had airway malacia, isolated, or in different combinations. Our results are consistent with the results of previously published studies conducted among NICU patients reporting a $48-52 \%$ incidence of airway malacia. ${ }^{[6,13,18]}$

Nosocomial pneumonia in pediatric and NICUs is associated with prolonged hospitalization, high mortality, and high health-care costs. Furthermore, pneumonia is the most common empirical antibiotic indication in the PICU. BAL may provide identification of the specific pathogen and may guide antimicrobial treatment. ${ }^{[19]}$ Several factors may affect the rate of detection of microbiologic etiology. According to the bronchoscopic studies among children with oncologic diseases, the early FB and BAL performed within $24 \mathrm{~h}$ of admission are associated with a high rate (74\%) of isolation of infectious agents, whereas the use of broad-spectrum antibiotics before FB reduce the growth of microorganisms in BAL. ${ }^{[20,21]}$ The early and frequent use of broad-spectrum antibiotics in neonates and relative later timing of FB may explain the lower yield of BAL in NICU. A study conducted in intensive care unit involving neonates and older children evaluated the yield of FB and $B A L$. The frequency of positive microbiologic BAL results related to patients' clinical condition was found as $56 \% .^{[14]}$ Another study conducted in NICU found that BAL specimens were positive for an organism in $33 \%$ of bronchoscopies performed. ${ }^{[22]}$ In our study, the rate of the patients with a positive microbiologic BAL result was $41.5 \%$ and comparable with other studies in the literature.

With the widespread use of bronchoscopy in children, the number of studies reporting the clinical diagnostic and therapeutic yield in different clinical groups is also increasing. Our results showed a high diagnostic and therapeutic yield of FB. Based on the definition, the rate of yield may differ between different studies. In a retro- 
spective study, Manna et al. ${ }^{[23]}$ investigated the diagnostic and therapeutic yield in PICU patients. They defined a positive bronchoscopic yield as a procedure that resulted in diagnosis related to the patient's clinical condition or in a change in management and found an overall yield rate of $76 \%$.

In nearly half of the patients, we revised medical treatments that included changes in antimicrobial therapy and the addition of pulmonary physiotherapy. Antimicrobial therapy, adjusted according to BAL culture results, provides rational use of antibiotics in NICU. Respiratory physiotherapy is commonly used in the treatment of children with tracheomalacia or tracheobronchomalacia, aiming to enhance mucociliary clearance, so we ordered regular physiotherapy in one-fourth of our patients. ${ }^{[17]}$

FB is widely used for therapeutic purposes including therapeutic lavage, removal of foreign body, and assistance with difficult intubations. In our study, the therapeutic use of FB was limited only to the removal of mucus plaques in children with persistent atelectasis. Therapeutic use of FB accounted for $14.6 \%$ of our patients, which was lower than studies reporting a rate of $24-27 \%$ conducted in PICU. [14,24] The success rate of therapeutic lavage is reported as approximately $75 \%$ in the literature. ${ }^{[10,14]}$ In our study, re-expansion occurred in all patients after FB.

Conservative treatments may be insufficient to maintain adequate airway patency and surgical interventions are required. Bronchoscopic imaging of the airways is very important in deciding surgical treatment in that case. Endoscopic evaluation is also of great importance for the success of surgical treatment, FB can clear levels and degree of obstruction and provide additional information that can prevent airway re-intervention in the pediatric airway and select the most appropriate type of surgical treatment. [25] In our study, in nearly $60 \%$ of the patients, the management changed from conservative to surgical based on the FB findings. Tracheostomy was the most commonly performed procedure. It is known that pediatric patients tolerate intubation longer than adults, but there are no established criteria regarding the timing of tracheostomy for children. ${ }^{[26]}$ The incidence of elective tracheostomy reported in the NICU is 34\%. ${ }^{[2]}$ Our result was consistent with the literature, FB allowed us to discharge one-third of our patients through tracheostomy.

FB is known as a safe procedure. There are limited data about the definition and measurement of the complications, which result in considerable variability in complication rates. de Blic et al. ${ }^{[28]}$ classified complications into two groups, minor complications, events that did not affect or preclude completion of the procedure, and major complications, all events that required intervention and termination of the procedure and reported the frequency of major complication at $<2 \%$. Several studies conducted in PICU and NICU reported no related mortality and showed that FB can safely be performed also in critical ill children. ${ }^{[5,14,15,22]}$ Although we were not able to record detailed data on complications, we did not observe any seri- ous complications which compromise the patient's clinical condition during or after FB.

Our study has some limitations. It is a retrospective, single-center study, with a small sample size. In addition, we could not assess minor and the post-procedural complications.

\section{CONCLUSION}

FB has an important value in the diagnosis and management of respiratory disorders in NICU without major complications. Direct visualization of the airways, microbiological assessment of BAL, and removal of mucus plugs allowed us to make an accurate diagnosis and provide appropriate treatment options, including airway surgical procedures.

\section{Ethics Committee Approval}

This study approved by the İstanbul Medipol University Non-Interventional Clinical Research Ethics Committee (Date: 02.07.2020, Decision No: 604.01.01-E.19393).

Informed Consent

Retrospective study.

Peer-review

Internally peer-reviewed.

Authorship Contributions

Concept: E.A., T.K., S.Ö.; Design: E.A, T.K, S.Ö; Supervision: S.Ö.; Materials: E.M., E.Y.K, B.V, S.G, Ö.M, F.Ü, H.A; Data: E.M, E.Y.K, B.V, S.G, H.A, Ö.M; Analysis: Ö.M, H.A, F.Ü, E.M, E.Y.K; Literature search: B.V, S.G, F.Ü.; Writing: E.A, T.K, S.Ö.; Critical revision: S.Ö.

Conflict of Interest

None declared.

\section{REFERENCES}

1. Myer CM, Thompson RF. Flexible fiberoptic bronchoscopy in the neonatal intensive care unit. Int J Pediatr Otorhinolaryngol 1988;15:143-7.

2. Tang LF, Chen ZM. Fiberoptic bronchoscopy in neonatal and pediatric intensive care units: a 5-year experience. Med Princ Pract 2009;18:305-9.

3. Midulla F, de Blic J, Barbato A, Bush A, Eber E, Kotecha S, et al. Flexible endoscopy of paediatric airways. Eur Respir J 2003;22:698-708.

4. Nicolai T. Pediatric bronchoscopy. Pediatr Pulmonol 2001;31:15064.

5. Peng YY, Soong WJ, Lee YS, Tsao PC, Yang CF, Jeng MJ. Flexible bronchoscopy as a valuable diagnostic and therapeutic tool in pediatric intensive care patients: A report on 5 years of experience. Pediatr Pulmonol 2011;46:1031-7.

6. Bhat JI, Charoo BA, Zahoor S, Ahmad QI, Ahangar AA. Role of flexible bronchoscopy in ventilator-dependent neonates. Indian Pediatr 2020;57:922-5.

7. Ferguson KN, Roberts CT, Manley BJ, Davis PG. Interventions to improve rates of successful extubation in preterm infants: A systematic review and meta-analysis. JAMA Pediatr 2017;171:165-74.

8. Pereira KD, Smith SL, Henry M. Failed extubation in the neonatal intensive care unit. Int J Pediatr Otorhinolaryngol 2007;71:1763-6. 
9. Fan LL, Sparks LM, Fix FJ. Flexible fiberoptic endoscopy for airway problems in a pediatric intensive care unit. Chest 1988;93:556-60.

10. Kohelet D, Arbel E, Shinwell ES. Flexible fiberoptic bronchoscopy -a bedside technique for neonatologists. J Matern Fetal Neonatal Med 2011;24:531-5.

11. Peroni DG, Boner AL. Atelectasis: Mechanisms, diagnosis and management. Paediatr Respir Rev 2000;1:274-8.

12. Tan B, Zhang F, Zhang X, Huang YL, Gao YS, Liu X, et al. Risk factors for ventilator-associated pneumonia in the neonatal intensive care unit: A meta-analysis of observational studies. Eur J Pediatr 2014;173:427-34.

13. Vijayasekaran D, Kalpana S, Ramachandran P, Nedunchelian K. Indications and outcome of flexible bronchoscopy in neonates. Indian J Pediatr 2012;79:1181-4.

14. Bar-Zohar D, Sivan Y. The yield of flexible fiberoptic bronchoscopy in pediatric intensive care patients. Chest 2004;126:1353-9.

15. Davidson MG, Coutts J, Bell G. Flexible bronchoscopy in pediatric intensive care. Pediatr Pulmonol 2008;43:1188-92.

16. Boogaard R, Huijsmans SH, Pijnenburg MW, Tiddens HA, de Jongste JC, Merkus PJ. Tracheomalacia and bronchomalacia in children: Incidence and patient characteristics. Chest 2005;128:3391-7.

17. Wallis C, Alexopoulou E, Antón-Pacheco JL, Bhatt JM, Bush A, Chang $\mathrm{AB}$, et al. ERS statement on tracheomalacia and bronchomalacia in children. Eur Respir J 2019;54:1900382.

18. Yan C, Hu Y, Qiu G, Gong X, Elda D. The clinical safety and efficacy of flexible bronchoscopy in a neonatal intensive care unit. Exp Ther Med 2020;20:95.

19. Foglia E, Meier MD, Elward A. Ventilator-associated pneumonia in neonatal and pediatric intensive care unit patients. Clin Microbiol Rev 2007;20:409-25.

20. Stokes DC, Shenep JL, Parham D, Bozeman PM, Marienchek W, Mackert PW. Role of flexible bronchoscopy in the diagnosis of pulmonary infiltrates in pediatric patients with cancer. J Pediatr 1989;115:561-7.

21. Efrati O, Gonik U, Bielorai B, Modan-Moses D, Neumann Y, Szeinberg A, et al. Fiberoptic bronchoscopy and bronchoalveolar lavage for the evaluation of pulmonary disease in children with primary immunodeficiency and cancer. Pediatr Blood Cancer 2007;48:324-9.

22. Mackanjee HR, Naidoo L, Ramkaran P, Sartorius B, Chuturgoon AA. Neonatal bronchoscopy: Role in respiratory disease of the newborn a 7 year experience. Pediatr Pulmonol 2019;54:415-20.

23. Manna SS, Durward A, Moganasundram S, Tibby SM, Murdoch IA. Retrospective evaluation of a paediatric intensivist-led flexible bronchoscopy service. Intensive Care Med 2006;32:2026-33.

24. Godfrey S, Avital A, Maayan C, Rotschild M, Springer C. Yield from flexible bronchoscopy in children. Pediatr Pulmonol 1997;23:261-9.

25. Maeda K. Pediatric airway surgery. Pediatr Surg Int 2017;33:43543.

26. Watters KF. Tracheostomy in infants and children. Respir Care 2017;62:799-825.

27. Mahida JB, Asti L, Boss EF, Shah RK, Deans KJ, Minneci PC, et al. Tracheostomy placement in children younger than 2 years: 30 -day outcomes using the national surgical quality improvement program pediatric. JAMA Otolaryngol Head Neck Surg 2016;142:241-6.

28. de Blic J, Marchac V, Scheinmann P. Complications of flexible bronchoscopy in children: Prospective study of 1,328 procedures. Eur Respir J 2002;20:1271-6.

\section{Yenidoğan Yoğun Bakım Ünitesinde Esnek Bronkoskopinin Önemi}

Amaç: Esnek bronkoskopi (EB) yenidoğan yoğun bakım ünitesinde (YYBÜ) yatan ve solunum problemleri olan hastaların yararına kullanılan bir araçtır.

Gereç ve Yöntem: Temmuz 20I4-Temmuz 2020 tarihleri arasında YYBÜ'de yatan ve EB yapılan tüm hastalar çalışmaya alındı. Demografik ve klinik özelikler, EB indikasyonları, EB prosedürüne ait veriler, EB bulguları, EB komplikasyonları ve EB'nin hastanın yönetimine sağladığı katkı değerlendirildi.

Bulgular: Kırk sekiz hastaya EB yapıldı. Bunların 22'si (\%45.8) erkekti. Medyan yaş 44 gündü (26.2-59.7). EB için en yaygın endikasyonlar; \%50 hastada ekstübasyon başarısızlığı ve \%33 hastada havayolu hastalığı idi. Bronkoskopik değerlendirmeler ile 46 hastada (\%95.8) en az bir anormallik saptandı. Kırk bir (\%85.4) hastaya bronkoalveolar lavaj yapıldı. EB, hastaların 46'sında (\%93.8) hastanın yönetimine katkı sağladı. Kırk sekiz hastanın I6'sına (\%33.3) bronkoskopi ile tanı kondu, 23 (\%48) hastada ise tıbbi tedaviler revize edildi. Hastaların yedisinde (\% |4.6) başarılı bir terapötik lavaj yapıldı. Hastaların 28 'ine (\%58.3) ise cerrahi girişim uygulandı.

Sonuç: Esnek bronkoskopi, YYBB'de solunum bozukluklarının tanı ve tedavisinde önemli bir değere sahiptir. Hava yollarının doğrudan görüntülenmesi, BAL'nin mikrobiyolojik değerlendirmesi ve mukus tıkaçlarının uzaklaştırılması, klinisyenlerin daha doğru tanı koymasına ve havayolu cerrahi prosedürleri dahil olmak üzere uygun tedavi seçeneklerini sunmasına olanak tanır.

Anahtar Sözcükler: Bronkoskopi; esnek; yenidoğan yoğun bakım ünitesi. 